\title{
Theory and Applied Relationships between FDI, FPI, Trade and Finance: Evidence from Jordan (1990 - 2009)
}

\author{
Jehad Aldehayyat ${ }^{1} \&$ Mohammad Alalaya $^{2}$ \\ ${ }^{1}$ Department of Business Studies, AlHussien ben Talal University, Ma' an, Jordon \\ ${ }^{2}$ Department of Economics, AlHussien ben Talal University, Ma' an, Jordon \\ Correspondence: Dr. Mohammad Alalaya, Department of Economics, AlHussien ben Talal University, Ma’ an, \\ Jordon. E-mail: dr_alaya@yahoo.com
}

Received: November 26, 2011

Accepted: February 16, 2012 Published: May 1, 2012

doi:10.5539/ass.v8n6p215

URL: http://dx.doi.org/10.5539/ass.v8n6p215

\begin{abstract}
This paper tests the Cusuality from trade to Finance, the relation between FDI and FPI and modified models which measures theoretical sense with production and government and taxation. We testify the impact of FDI, with Economic growth rate represents of growth rate of (GDP) and with capital defer Maries. Researcher investigate the intertemporal linkages between FDI and dis aggregate measures of trade in Jordan applied with (linear) and (No linear) methods after pooling the data.

Researcher found strong evidence of auto correlation in the association between FDI and Gross flows and trade is positive and significant at the $95 \%$ level For Jordan. Decomposition of measure for trade openness in to trade in goods. In services and in incomes how ever, yields very similar statistically significant results, In addition the results for other macroeconomic and political control variables are reported in the discussion of Results.
\end{abstract}

Thus many alternative specifications of our empirical model in order to verify the results of mode

Keywords: FDI, FPI, rate of taxation, host country, Jordan, trade, financial openness

\section{Introduction}

In this paper researchers attempt to provide a new look of the mechanisms through which FDI relation with Trade, FDI and FPI, Then corporate Tax rates influence aggregate FDI flows (Note 1). The increasing importance of FDI and it is components and it is directions, therefore a growing literature has recognized the existence in two ways feed back between financial flows and Trade for developing countries, Yet it clears aggregate measures of both financial flows and Trade openness. It is reasonable to expect that the link between FDI and trade in goods possibly bi-directional, whereas it is less evident, whether the impact of trade of FDI should vary from an investment patterns which referred horizontal. While cost gaps may encourage producers to fragment the production process, putting Labor intensive stages of production in low wage countries.

Some investment patterns are referred as a vertical, the importance difference between these two patterns deals with the associated between FDI and trade, where vertical FDI tends to create trade, ahorizantal FDI tends to substitute trade. Thus the economic reasonable expect that vertical FDI are more prevalent between the industrialized and developing countries.

Most of the literature studies investigated FDI patterns focus on cross country variation. Therefore this paper is an attempt to focus on the interaction and impacts between trade and FDI over time. And investigated possible intertemporal feed back effects between trade \&FDI. The researcher notice that the rapid improvement in it is productivity will attract growing inflows of vertical FDI, Thereby increasing it is international trade. The vertical FDI ought to increase the demand for skill workers, increasing the return to human capital in developing countries hence, increasing supply of skilled workers, and potentially increasing the future flows of FDI.

The researcher notice that in the study data of international trade, the argument that larger inflows of FDI will increase volume of trade as well as other benefits such as increased rates of total factors of productivity growth. Foreign direct investment (FDI) and foreign portfolio investment (FPI), an empirical regularity is that share of FDI in total foreign equity flows is lager for developing Countries. In hence, we notice that foreign equity flows 
that the volatility of FDI Net flows in general much smaller than that of FPI Net flows, and the difference in volatility between FPI and FDI flows are much smaller for developing countries.

Despite the interest in foreign equity flows, the rigorous theoretical framework which explaining (FDI and FPI) should be declared in this paper. The particular interest of this era of increasing globalization is the effect of international differences in tax rates on foreign direct investments (FDI). Thus the third part of this paper concern with the effects of the difference in tax rate on(FDI $\}$. We specify two types of lumpy set costs for new investment; the first reflects is the initial cost that an FDI investor has to manage the project directly. This cost is exogenously in the model. The second type is information based cost, is derived endogenously in the model. It is results from the possibility that investor need to sell their investments before maturity because they face liquidity shocks. The recent studies in the FDI papers have examined the empirical identifiable interaction between financial flows and trade (lipsey2002, Do\& levchenko, 2004, Rose and spiegl, 2004, and Blonigen, 2005).

Many of recent paper have examined the identifiable inter actions between financial flows and trade (Albuquerque etl, 2005, Do and levchenko, 2004, Lane and Milesi, ferretti, 2004, and 2005), most prominent in this literature is the argument that larger in flows of FDI will lead to higher volume of trade. (Perez, Gonzales, 2005), shows that after a foreign investor establishes opposition that is greater than $5 \%$ of the firms shares and the firms productivity.

Chari, Quimet and Tesar 2005 demonstrate the affair, a process of diversification finance rather than development finance. (Melitz and Yeuple, 2003) prove that the trade based typically focuses on issues such as the independent of FDI and trade in goods and in industrial structure. (Aizeman and Noy 2004), examined de facto measures of financial and trade openness and show the aggregate financial and commercial openness measures are closely linked.

Holthausen, Left and Mayers 1990, Chan and lakenishok1995 find that the large price impact than a sale by other investors can be supported by two stands, first it has been shown that the sale of stocks by large block holders has a bigger down ward effect on the price than sales of stocks by other holders. second perhaps the evidence on the price impact in the presence of control can be obtained by looking at what happens when the firm sells it is own shares finance literature has documental the large decrease in price following an announcement by the firm that is going to sell new equity, (see, korajczyk, lucas, and Mc Donald 1991, and Downess \& heinkel1982, also (Lane, 2004) and Razian et al, 2003).

Therefore the paper focuses in modeling the $(a, b, c)$ parts of research, Then to focus on aggregate bi lateral FDI, Thus trade based on applications typically use micro data set, whears we utilize this data to analysis the effect of FDI and its impacts of trade and FPI and rate of taxation, therefore we have modulates an econometric models depends on Non linear relation between the dependent variable and independent our finding that strong impact between FDI and trade,FPI.

Thus the paper divided into five sections, first included introduction which indicates to recent and literature review of subject of paper, second part is theory which related of research, and bi results of theory some corollaries. Third section of paper contains the sources of data and methodology. Fourth section is empirical results, fifth section included concluded remarks.

\section{Theory}

\subsection{Possible Links between Trade and FDI}

Propose an interest group theory of financial development where by incumbents oppose financial development because it braces competition. The other channel operating from finance to trade might by due to reliance of international trade on trade credits. an alternative channels explaining the feed back between FDI and trade deal with the endogenous determination of patterns of production and investment in human capital by-products of the fragmentation is the growth of tow - way trade: higher imports of primary and intermediate products, followed by higher exports of the improved a final products due to accumulation of human capital learning by doing. or better institutions will attract growing inflows of vertical FDI might increasing international trade, but sure vertical FDI ought to increasing the demands for skill workers, in other hand it will increase the supply of skilled workers, further result increasing future FDI.

\subsection{Causality from Finance to Trade}

The granger causes FDI gross flaws openness by past trade opposites to present trade openness the opposite specification estimates as:

$$
\mathrm{Co}_{2}(\text { goods })=\mathrm{y}+\sigma_{1} \mathrm{xit}+\sigma_{2} \text { Fo } 11+\mathrm{N}_{\mathrm{n}}
$$


LHs variable is the openness of goods trade, and RHs in clued a set of control variables (chosen incrementally), and various measures of financial openness (FDI, loans, equity and trade credits).

The FDI openness measure appears to have statistically significant and large effect on trade of goods. Consider that a global economy composed of 2 blocks of countries, $\mathrm{H}$ and $\mathrm{F}$, each consuming two types of fined goods, a homogeneous one, 2 , and heterogonous goods, denoted by yt $-1.1=1$.

A semi additive function of two goods utility of $\mathrm{H}$ consumer can be written

$$
u_{t}=z_{t}+\sum_{1=1}^{n}\left|y_{t, 1}\right|^{\infty} \begin{aligned}
& 0<s< \\
& 1 \ldots \ldots
\end{aligned}
$$

The supply of labor in each block is inelastic and good 2, in this technology as:

$$
2=\mathrm{L}_{\mathrm{S}}
$$

$\mathrm{L}_{\mathrm{S}}$ : labor employed in the production of the homogenous sector.

Sector in the developing countries is:

$$
2 *=\mathrm{A}^{*} \mathrm{LS}^{*}
$$

Where parameter $\mathrm{a}^{*}$ is composite hood.

Due to the reasons elaborated in the literature dealing with vertical FDI, if the intermediate input mi be produced in the foreign country at time by using a cob - Douglass production technology

$$
M_{t}, 1=\sqrt{b^{*} L_{t}^{*}, I}
$$

Where $\mathrm{L}_{\mathrm{t}},{ }^{*} \mathrm{I}$ is the labor employed and $\mathrm{b}_{\mathrm{t}}{ }^{*} .1$ is labor productive $\mathrm{t}_{\mathrm{y}}$ in the foreign intermediate

T-good factory a leontief technology to supply the final output, $\mathrm{y}_{\mathrm{t}}^{\mathrm{s}}, 16$

$$
\mathrm{Yt}_{\mathrm{t}, 1}^{\mathbf{s}}=\operatorname{Min} \mid \mathrm{m}_{\mathbf{t}} 11, \sqrt{\mathbf{B i}_{\mathrm{t}, \mathrm{l}}}
$$

The demand for goods y in each country

$$
Y_{t}^{d}=\left(A / P_{y}, i\right)^{n} ; \Delta r=\frac{1}{1-Q P}>1
$$

We assume that goods(y and I) are ordered such that a higher index is associated with higher periodic set-up cast. and the monopoly profits are

$$
I_{1}=a r_{1} P_{, 1}-w_{1+1}^{*}-2 c_{0}
$$

And the first order condition characterizing optimal out put

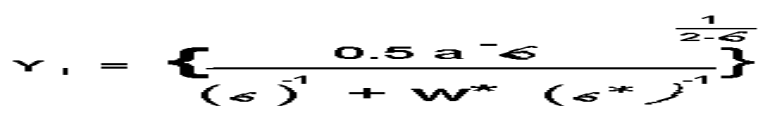

The highest $\left(\mathrm{b}^{*} / \mathrm{a}^{*}\right)$. Hence a developing country that gains productivity in activity I that exceeds its competitors will attract more FDI.

The export of such a country would in crease Beth due to higher production level of the infra marginal goods.

These we assumed that the productivity improvements are exogenous, as will be the exogenous accumulation of human capital.

Conflicting effects of productivity (1)

The determinants FDI flow from the source country (F) to the hoset country 
(h). a host country Firms suppose that the source - country entrepreneur are endowed with some intangible capital.

(1)- formore, |"see: Eichengreen (2002) and hutenison and Noy (2005) and srangeri (1969) sims (1972) |thus, an increase in the host country productivity factor $(\mathrm{A} \mathrm{H})$ rises the volume of FDI flows from country( $\mathrm{s}$ ) to country $(\mathrm{H})$ that is governed by the flow equation but, at the same time, the rise in $\mathrm{AH}$ increases also the value of the domestic component of the set up cost, $\mathrm{W}_{\mathrm{H}}\left(\mathrm{A}_{\mathrm{H}}\right)^{1 \mathrm{c}} \mathrm{H}$.

The FDI flow mechanism works as follows. A country is based on low set up costs of direct investment, relative to set up cost of domestic investor. this allows foreign investors to bid up for investment projects in the host country, an exogenous productivity chock in the host country may effect the decision of the FDI investor .

\subsection{FDI \& FPI}

\subsubsection{Expected Value of FDI}

Investor I get a liquidity chock, and sell the project in period 1 . With probability $\mathrm{N}$ i which perceived by market and the market price is:

$$
\left.P_{1}, d x d\right)=\frac{1+E E_{0}\left(N_{0}\right)^{2}}{2 A-}
$$

With probability (1- $\lambda$ i\} doesn't get liquidity chose, he sells the projects if the realization of $E$ is below $E_{D}\left(N_{D}\right)$, A direct investor has to in cur a fixed cost of C. There by the EX- value can be as:

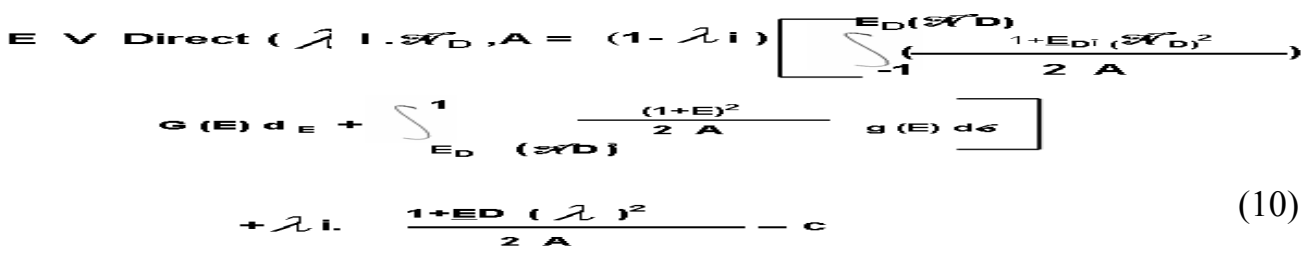

Where $\mathrm{p}, \mathrm{d}$ end $\mathrm{ED}$ as a function of the market perceived probability.

\subsubsection{Expected Value of FDI}

When the investor hold the investment as a portfolio investment with probability

he receives a liquidity shock the selling is:

$$
P_{1}, P=\frac{1}{A}
$$

With probability 1-- the investor does not receive a liquidity shock. the expected pay off is.

$$
\frac{E(1+Z E)}{2 \mathrm{~A}}=\frac{1}{\mathrm{~A}}
$$

The ax - ante expected pay off from aport0 folio investment can be written as:

$$
\text { EV PROTFOLIO }(A)=\frac{1}{2 A}
$$

\subsubsection{FDI vs FPI}

We define the difference between the expected value of FDI and the value of FPI as follows:

$$
\text { evportfolio (a) }
$$

There fore the investor (I\} will choose FDI when $\operatorname{diff}(\mathrm{n} \mathrm{I}, \mathrm{n} \mathrm{d}, \mathrm{a})<0$ and will choose FPI when diff (n i, n d, a) also studies the effect of different parameters on the function

Diff ( $\mathrm{N} \mathrm{i,} \mathrm{N} \mathrm{d,} \mathrm{a)} \mathrm{and} \mathrm{us} \mathrm{on} \mathrm{the} \mathrm{choice} \mathrm{between} \mathrm{the} \mathrm{two} \mathrm{forms} \mathrm{of} \mathrm{investment.}$

We can notice a feature of the equilibrium out comes. It is organized in three Corollaries as below: 


\subsection{Corollaries}

Corollary 1: if FDI and FPI co exist in the equilibrium thin the expected liquidity needs of FDI investor are lower, an average, and then the expected liquidity needs of FPI investors

FDI Investors are of ten large and stable multinational companies, With low expected liquidity, needs, whereas FPI investors such as global mutual funds ) are, on average more vulnerable to liquidity shocks this result contributes to the high with drawl ratio of FPI relative to FDI.

Corollary 2: as the cost of production in the host country the predict in creases there will be more FPI and less FDI in equilibrium thus the predicated that developed countries will attract more $\mathrm{f} p$ I whereas developing countries will attract more FDI. this indeed consistent with empirical evidence while developed countries have higher costs of productions and thus lower profitability of investments Projects, there for in these pay the fixed costs it is less beneficial to pay the fixed costs associated with establishing an FDI investment

Corollary 3: there is a heterogeneity on any investors in creases a separating equilibrium - with a large difference between the withdrawal rate of FDI becomes more like.

\subsection{Government}

Each government balances its budget; tax revenues must suffice to finance public expenditures, (walres law) titled that the government's budgets constraints can be replaced by an economy-wide resource constraints. The tax which paid by a firm owned by foreign investors (FDI) reflects the cash flows of the firm, and prices after tax which serve the finance public expenditure. The source country effectively subsidizes the host country through the tax deductibility of fixed setup costs, (through the foreign tax credit). There for we considered the foreign tax as subsidiary to the host country. Due to conventional thinking, and the tax ratio which imposes by the government of FDI firms (a firm owned by a foreigners) increasing the prices as:

$$
\begin{array}{ll}
\mathrm{Qs}= & \mathrm{c}+\mathrm{bpt} \\
\mathrm{Q}= & \mathrm{c}+\mathrm{b}(\mathrm{ll})
\end{array}
$$

and the equilibrium state under the equilibrium condition is:

$$
\begin{aligned}
& \mathrm{p}^{*}=\mathrm{p} 0+\mathrm{d} \quad \mathrm{t} \\
& \text { d b }
\end{aligned}
$$

Where $\mathrm{P}^{*}$ equilibrium price po initial price and $\mathrm{d}, \mathrm{b}$ parameter $\mathrm{S}$ of the model and $\mathrm{t}$ ratio of tax. As the previous results, the government gain (d/(d-b))*t after imposing the tax on FDI. Economic growth measures the growth of GDP in the country. Thus our application represents the following models

$$
\begin{gathered}
\mathrm{Gdp}=\mathrm{f}(\mathrm{Ds}, \mathrm{fdi}, \mathrm{X}, \mathrm{L}) \\
\mathrm{DC}=\mathrm{f}(\mathrm{FDI}, \mathrm{FC}, \mathrm{YPC}, \mathrm{X})
\end{gathered}
$$

Where, Gdp is gross domestic product, DS (saving), FDI (foreign direct investments, (X)experts, (L Labor force) DC (capital deformity) Ypc (per capita of income). FC Foreign investment despite FDI. We notice that the first equation is neo classical production function contains export as added variable to measure the effect of on economic growth. And the models can be specified as the models are estimated by two methods, linear and Non linear methods, the tests are consists of $(\mathrm{t}$-test) to measure the significant of parameters, $(\mathrm{F}$ test) to insure of the if the model and variables in best model, represents all variables affected with GDP. (R2) to test the good of fitness of the model. And (D.W) to testy the model. Serial and auto correlation with in residuals of the models. And (Klein Test) to cheek weather the models has a multi colinearity problem. Lastly we have used (Theil in equality forecasting test).

$$
U=\frac{\sqrt{\frac{1}{11} \sum(\hat{y}-y)^{2}}}{\sqrt{\frac{1}{1} \sum(\hat{y})^{2}+\sqrt{\frac{1}{11} \sum \sqrt{(x)^{2}}}}}
$$

We have used the multivariate estimation method in order to investigate whether the past trade openness Granger-causes FDI gross flows openness, we start by positing a linear structure model as

$$
\text { FDIti }=\mathrm{a} 1+\mathrm{b} 1 \mathrm{xit}+\mathrm{b} 2 \mathrm{Ct}+\mathrm{Ue}
$$

Where dependent variable FDIti $(\mathrm{Q})$ at time $\mathrm{t}$ and Type $\mathrm{Q}$ (gross, net inflow, vector of xit of micro-economic and

political - instructional control variable, a vector of average lagged trade openness measure $\overline{\boldsymbol{C O}_{\mathrm{It}-1}^{\mathrm{T}}}$ at time T 
and type $\mathrm{T}$ (goods, services ). Tables I \&2 in context include the data-base for basic regression (GDP,X LA bar FDI, $\left.D^{S}\right)$, the variables which represents the non - liner model $\left(R^{2}\right.$ is 0.9849$)$. These depend on the macro economic controls that are included in the estimation models (the specific LHS labor, Export, FDI, D saving. the estimated model is:

$$
\mathrm{GDp}=\mathrm{x}(0.843) * \operatorname{LAB}(0.09775) * \text { FDI }(0.2006) * \mathrm{DS}(-0.00124)
$$

The variable in the model in best model due to F-Ration $240.14>$ (prob level)

T. value for $\mathrm{B}^{1,} \mathrm{~B}^{2,} \mathrm{~B}^{3}>$ (probe level) thus we reject $\mathrm{Ho}: \mathrm{B}=0$, the variables effected with dependent variable (GDP), and the independence variables explain the changes that happens in GDP. as $98 \%$ while b2 is not significant. The forecast estimation due to the result are, if export (trade) increases $1 \%$ the GDP increases 0.834 , while labor (Skill worker) increases in 1\% the GDP increases 0.0977 also FDI has a positive relation and increases $1 \%$ the GDP increases 0.2006 then domestic saving has inverse relation GDP decreases 0.001 , Total sum of squares is (456872600) when we attempt to apply the multiple regression the standard deviation for all variables in the confidence limits (maximum and minimum), While the normality tests section assigned that significant at level 5\% (Accepted) normal distribution. Thus the effected relation between FDI to GDP is positive relation $(0.20\}$, and export increases in $(0.83)$, and most direction of FDI to export manufactured in developing contrary and also the case of Jordan in addition on the specification discussed.

We tested FC (capital formation) as: a dependent variable with the independent variables (exports, YPC, FDI, investment), two moments regression analysis has been used to estimated the model results of estimation as:

$$
\mathrm{FC}=\mathrm{X}(0.80) * \mathrm{ypc}(-0.1187) * \mathrm{FDI}(0.0055) * \text { invest }(0.228)
$$

F- Ratio (17.73) $>$ I prob level I. Thus the variable represents the model. and the $t$ - value conformed the relation between variables in depends the $\mathrm{R}^{2}$ as good of fitness as $(0.829)$, relationship between dependent variable and independent as following negative (YPC), dependent FC equal(0.12) and export (X) is too height due to increased (0.80) FDI has appositive relationship, but it's too weak with FC if FDI increased 1\% FC increased 0.005 .

\section{Data and Methodology}

The data used in this study is the annual flows of FDI, capital formation, trade (export and import), gross domestic product, taxations. The data are expressed in 1990- 2010 evaluated in fixed prices, in order to get red of effect of inflation in variables, the inflation increased since 1987 in Jordan, data has been collected from different sources such as:

1) Central bank of Jordan (several reports issued).

2) International financial statistics (I.F.S) several issued.

3) Department of Jordanian statistics (D.O.S).

4) I.M.F yearly reports, several issued.

5) Arab unified economic reports (several issues of report).

The variables under investigation are GDP denotes to real gross domestic product, FC is gross capital deformities in Jordan, where $\mathrm{M}$ denotes to import of goods and services, FDI denotes to foreign direct investment, FPI is foreign portfolio investments. to apply the analysis due to choose the suitable procedure for this purpose, we should apply ADF test, PP-Pearon test, supported by a test of LP (Lumsdaine - Papell) test which introduced a novel procedure to capture two structural breaks in series, and thy fund that two structural breaks are more powerful than the single breaks, and this paper we have the same results. Then descriptive statistics results drown, to check of normality distribution of data, and autocorrelation and partial correlation, and VAR model, and response of FDI on all variables, then TOBIT model is used as censored with QML(Huber /White ) to have results of data analysis, correlogram of standardized residuals of analysis used to insure of results, then I have check the coefficients parameters by Wald test.

\subsection{Assumptions}

We have many assumptions in this paper as follows:

1) if data has a unit root or not, which model is suitable to data analysis such ARDL model or VAR models, and the short-run adjustment is positive and high, also long-run equilibrium relation is high.

2) export effects capture the positive externality effects on economic growth. 
3) the relationship between FDI flows with GDP and trade( export, import) is increased and has a positive sign over time.

4) A FDI effect of capital deformities reflects a positive effects but it has small ratio as results of analysis.

\section{Empirical Results}

First step we have done the ADF and PP tests to insure of stationarity of data, results of analyses are presented in Table 1.

Table 1. Augmented dickey -fuller and Philips - pearon tests results

\begin{tabular}{lllll}
\hline Variables & ADF -test 1 & PP-test 1 & ADF $1^{\text {ST }}$ diff & PP- $1^{\text {st }}$ diff \\
\hline GDP & 1.82216 & $-8.1639^{* *}$ & -2.1659 & $-3.6150^{* * *}$ \\
M & 0.607908 & $-3.7276^{* *}$ & 0.785157 & $-3.78917^{* *}$ \\
X & $-4.59653^{* *}$ & & -2.92292 & $-3.93358^{* *}$ \\
FC & -2.296557 & $-4.43798^{* * *}$ & -2.28344 & $-5.7637^{* * *}$ \\
FDI & -2.543731 & $-4.09386^{* *}$ & $-6.06528^{* * *}$ & \\
\hline
\end{tabular}

* Significant at $5 \%, 10 \%$ levels. ${ }^{* * *}$ Significant at $1 \%, 5 \% .10 \%$ levels.

PP-test: lag truncation for Bartlett Kernel 3 (New -West suggests 3).

As results of Table2 most of variables under investigation in levels are not stationary, while it is stationary in first difference, the results in table used intercepts and trend only. The structural breaks reported in Table 2.

Table 2. Test unit results allowing for two structural breaks

\begin{tabular}{llllll}
\hline Variables & TB1 & TB2 & t-statistic & $\mathrm{k}$ & $\begin{array}{l}\text { Results } \\
\text { Ho:unit root }\end{array}$ \\
\hline Ln M & 1985 & 2010 & $-10.63^{* * *}$ & 6 & reject \\
Ln x & 1995 & 1994 & $-6.385^{*}$ & 8 & reject \\
Ln GDP & 1976 & 2010 & $-9.1432^{* *}$ & 12 & Not-reject \\
Ln FDI & 1983 & 2010 & $-5.733^{* *}$ & 4 & reject \\
Ln FPI & 1989 & 2010 & $-8.435^{* * *}$ & 7 & reject \\
\hline
\end{tabular}

** 5 percent level significant. $* * * 10$ percent level significant.

The results of table of structural breaks in both the slope and intercepts shows a strong evidence against unit hypothesis, and all results shows that all variables under investigation reject unit root hypothesis, and two structural breaks a strong evidence than one structural breaks. Second step is to analyze the data with out the data of FPI using the OLS regression results are stated in Table 3.

Table 3. Least squares results of data omitted from data

Dependent Variable: GDP

Method: Least Squares

Included observations: 35

\begin{tabular}{crlrr}
\hline Variable & Coefficient & Std. Error & t-Statistic & Prob. \\
\hline M & 0.508594 & 0.083800 & 6.069131 & 0.0000 \\
X & 1.584405 & 0.174259 & 9.092230 & 0.0000 \\
FC & -0.172068 & 0.295791 & -0.581723 & 0.5651 \\
FDI & -0.322405 & 0.314395 & -1.025480 & 0.3133 \\
C & 228.7462 & 102.5516 & 2.230547 & 0.0333 \\
\hline R-squared & 0.969548 & Mean dependent var & 4410.633 \\
Log likelihood & -268.4985 & F-statistic & 238.7918 \\
Durbin-Watson stat & 0.816537 & Prob(F-statistic) & 0.000000 \\
\hline
\end{tabular}

The data fitted well, $\mathrm{R}^{2}$ is 0.9695 , and the model fitted the data according the prob (F-statistic) 0.000 , the effect sign of FDI is negative, due to the size of FDI effects as long -run of 19976- 2010, if we considered the structural breaks of this long period, where FC has the same effected, the model can be written as following:

$\mathrm{GDP}=228.7462+0.5086 \mathrm{M}+1.5844 \mathrm{X}-0.1720 \mathrm{FC}-0.3224 \mathrm{FDI}$.

Log likelihood is -268.4985 , were Durbin Watson indicates that there is no serial correlation. But TOBIT model supported the least square regression, results are states in Table 4. 
Table 4. ML- Censored normal (TOBIT) results of data

Dependent Variable: GDP

Method: ML - Censored Normal (TOBIT)

\begin{tabular}{|c|c|c|c|c|}
\hline & Coefficient & Std. Error & z-Statistic & Prob. \\
\hline $\mathrm{M}$ & 0.508594 & 0.077584 & 6.555432 & 0.0000 \\
\hline $\mathrm{X}$ & 1.584405 & 0.161332 & 9.820761 & 0.0000 \\
\hline $\mathrm{FC}$ & -0.172068 & 0.273848 & -0.628334 & 0.5298 \\
\hline FDI & -0.322405 & 0.291072 & -1.107649 & 0.2680 \\
\hline $\mathrm{C}$ & 228.7462 & 94.94406 & 2.409273 & 0.0160 \\
\hline \multicolumn{5}{|c|}{ Error Distribution } \\
\hline SCALE:C(6) & 519.2815 & 63.25138 & 8.209804 & 0.0000 \\
\hline R-squared & 0.969523 & \multicolumn{2}{|c|}{ Mean dependent var } & 4410.633 \\
\hline Adjusted R-squared & 0.964268 & \multicolumn{2}{|c|}{ S.D. dependent var } & 3019.199 \\
\hline S.E. of regression & 570.7142 & \multicolumn{2}{|c|}{ Akaike info criterion } & 15.68563 \\
\hline Sum squared resid & 9445726. & \multirow{2}{*}{\multicolumn{2}{|c|}{ Schwarz criterion }} & 15.95226 \\
\hline Log likelihood & -268.4985 & & & 15.77767 \\
\hline Avg. log likelihood & -7.671385 & & \\
\hline
\end{tabular}

\section{Conclusion Remarks}

This paper provides stylized analogue of the prediction of FDI relation to GDP, Trade, Tax and FPI. The empirical results are presented in consistence with the feedback effect between FDI, and trade that are stronger in developing countries, also in Jordan as we applied.

We presented an econometric Models of the impacts of FDI with economic growth rates in Jordan $(1990,2004)$, then with capital deformities, also we investigating the interemporal linkages between and other aggregate measures of trade in Jordan.

The strong evidence of Auto correlation in the aggregate financial openness measures has been noticed, when we testify the two models to multicollinearity in (klain test), we noticed that it is not a problem, even when we testify the evidence of the models (Thiel, inequality test\}, we found the first model is 0.54 and the capital deformities model is 0.48 , The results are remarked as significant statistically.

Finally the observed positive association between Trade and finance attributed to political economy factors. The prediction seems that countries domestic financial development should be positive correlation with Trade openness.

Another notice worthy is that ED IS always below 0 , and consequently P1, D in all ways below 1|2A, This feature plays an important rule of comparison between the resale price of portfolio in investment and resale price of FDI.

\section{References}

Auer bach, A. J, \& L. J Kotllikoff. (1987). Dynamic fiscal policy. Cambridge, MA: Cambridge University press.

Auerbach Alanj, \& kevin Hassett. (1993). Taxation and foreign direct invest means in the united states: Arelonsid evaluation of the evidence. Al Berto Giovanni I.

Bliongen, B.A. (2005). A review of the Empirical Literature on FDI Determinants. NBER working paper 11299.

Caballero, Ricardo, \& Eduardo Engel. (1999). Explaining investment dynamics in US manufacturing: A Generalized Approach. Econometrica, July, 741-82.

Chan, K. K., \& Genmayel, E. R. (2004). Risk instability and pattern of foreign Direct investments in the middle east and north Africa Region. IMF working paper 04/139,

De Mooij, R. A., \& S. Ederveer. (2001). Taxation and foreign direct investment a synthesis of Empirical Research. Cesifo working paper NO 588.

Eaton Jonatham, \& Akiako Tamura. Bi-literalism and Regionalism in Japanese and U.S Trade and direct investment. Journal of the Japanese and international Economics, 8, 478-510.

Feenstra, R. (2003). Advanced international trade theory and evidence. Princeton university press.

Froot, K. A., \& J. C. Stein. (1991). Exchange Rates and foreign direct investment. An imperfect capital markets approach. Quarterly journal of economics, 106, 1191-1217. 
Gellen Hubbard, \& Joel Slemord (eds). Studios in international taxation. University of Chicago press, 119-144.

Geweke, D, Meese, \& Rdent, W. (1988). Comparing alternative test of causality in temporal system, and results and Experimental Evidence. Journal of Economics, 21, 161.

Granger, C. W. J. (1988). Some resent developments in a concept of causality. Journal of Economics, 39, 199-212.

Hall Robert, E., \& Dale W. Jorgenson. (1967). Pox policy and investment behavior. American Economic review, $57,391-414$.

Helpman Elhanan, Mark Meltiz, \& Steve Yeuple. (2004). Exports vs FDI with Heterogeneous firms. American Economic Review, 94(1).

Lame P. R \& Milesi-Ferretti, G. M. (2005). A Global perspective on External positions. IMF working paper $\mathrm{wp} / 05 / 16$.

Lipeey, R. E. (2002). Home and host country effects of FDI Nbe. Working paper No 9293.

Lipsey, R. E. (1999). Foreign direct investments in international capital flows. NBE" working paper, 7094.

Lipsey, R. E. (2001). Foreign direct investors in three financial crises. NBER working paper, 8084.

Obst Feld, Maurice, \& Alan M. Taylor. (2003). Globalization and capital markets.

Razian A., \& E. Sadaka. (2003). Gains from FDI in flows with incomplete information. Economic Letters, 7, 71-77.

Razian, Assaf Efraim Sadka, \& Huitong. (2004). Bilatera FDI flows threshold Barriers and productivity shocks. NBER working paper -11639 .

Santos Silva, J. M. C., \& Tenreyro Silvana. (2003). Gravity-defying trend. Working paper 03-1, Federal Bank of Boston.

Swenson. D. L. (2004). Foreign investment and the mediation of trade flows. Review of International Economics, 12(4), 609-629.

William Son (ed.). Globalization in historical perspective. University of Chicago press.

World Bank. (2003). World development index. Cambridge, MA: Cambridge University.

Note

Note 1. For a summary based on A\} Lapsey $(1999,2001)$, shows that the ratio of FDI volatility to other long term flows volatility is 0.59 in Latin America, 0.74 in south east Asia, 0.86 in Europe, and 0.88 in usual. Thus the differences in volatility between Net FDI in flows and other types of Net flows are smaller in developed economics for more illustration, see (perez, quiros and Popper, 1999, Lipsey 2001 and Sermo\&Taylor, 199]. 